\title{
Comparison of Energy Consumption for Different Sowing Techniques and Seed Rate of Direct Seeded Rice (Oryza sativa L.) under Medium Land Situation of Manipur
}

\author{
K. Nandini Dev ${ }^{1}$, Herojit Singh Athokpam², K. Khamba Singh ${ }^{3}$, \\ M. Anandi Devi ${ }^{3}$ and O. Gojendro Singh $^{4}$ \\ ${ }^{1}$ Department of Agronomy, College of Agriculture, Central Agricultural University, Imphal- \\ 795004, Manipur (India) \\ ${ }^{2}$ Department of Soil Science and Agricultural Chemistry, College of Agriculture, Central \\ Agricultural University, Imphal-795004, Manipur (India) \\ ${ }^{3}$ Department of Biochemistry, ${ }^{4}$ Department of Zoology, Manipur College, Imphal-795008, \\ Manipur (India), India \\ *Corresponding author
}

\section{Keywords}

Direct seeded rice, energy productivity, seed rate, sowing technique

Article Info

Accepted:

05 February 2020

Available Online: 10 March 2020

\section{A B S T R A C T}

A field experiment involving two sowing techniques (broadcasting and line sowing) and five different seed rates $(80,90,100,110$ and $120 \mathrm{~kg} / \mathrm{ha}$ ) with a total of ten treatments in factorial randomized block design with three replications to compare the energy consumption for different sowing techniques and seed rate of direct seeded rice (Oryza sativa L.) under medium land situation of Manipur was conducted during kharif 2016 at Research Farm of College of Agriculture, Central Agricultural University, Imphal. The result revealed that highest total energy input was observed from broadcasting of seed at the rate of $120 \mathrm{~kg} / \mathrm{ha}(17790 \mathrm{MJ} / \mathrm{ha})$ whereas the lowest total energy input (17135 MJ/ha) from broadcasting of seed at the rate of $80 \mathrm{~kg} / \mathrm{ha}$. In contrast highest output energy $(217542 \mathrm{MJ} / \mathrm{ha})$, energy efficiency and highest energy productivity of grain (0.35) were obtained from line sowing with seed rate $100 \mathrm{~kg} / \mathrm{ha}$. Energy intensity shows that the highest energy consumption was from broadcasting of seed at the rate of $120 \mathrm{~kg} / \mathrm{ha}(3.44 \mathrm{MJ} / \mathrm{ha})$ and the lowest from line sowing with seed rate $100 \mathrm{~kg} / \mathrm{ha}(2.90 \mathrm{MJ} / \mathrm{ha})$.

\section{Introduction}

Rice cultivation requires many consuming operations such as energy tillage, transplanting, irrigation, application of fertilizers, agro-chemicals for plant protection, harvesting, transportation etc. In order to sustain agricultural production, 
effective energy use is required, since it provides ultimate financial saving, preservation of fossil resources and reduction of environment distortion. The energy consumption in the agricultural sector depends to the population employed in the agriculture, the amount of cultivable land and the level of mechanization (Ozkan et al., 2004). In the present era of energy crisis, for formulating any policy on energy use and conservation, it is imperative to examine the pattern of energy consumption for agricultural production especially rice.

Since efficient use of the energy resources is vital in terms of increasing production, productivity, competitiveness of agriculture as well as sustainability of rural living, energy auditing is one of the most common approaches to examining energy efficiency and environmental impact of the production system. It enables researchers to calculate output-input ratio, relevant indicators, and energy use patterns in an agricultural activity (Adem et al., 2006). When a natural system capable of producing a certain amount of energy containing biomass is converted into an agroecological system, the natural capability limit is often exceeded by adding energy inputs. The greater the input of external energy, the more the natural capability of the system can be exceeded, and the less sustainable the system becomes. Because of this relationship, an analysis of agro-ecosystem's input/output energy balance can be a comprehensive indicator of its sustainability (Farshad and Zinck, 2001). In this regard, efficient use of energy by the agriculture sector seems as one of the conditions for sustainable agriculture because it allows financial savings, fossil resources preservation and air pollution decrease (Pervanchon et al., 2002).

Energy requirement in agriculture are divided into two groups - direct and indirect. Direct energy is essential in performing various tasks related to crop production processes such as land preparation, planting, crop management, irrigation, harvesting, post-harvest operations and transportation of agricultural inputs. Energy that is used directly at farms and fields are fuel, electricity and human energy. On the other hand, indirect energy consists of energy used for fertilizer, pesticides, seeds and farm machinery. Paddy production is one of the most energy intensive production systems. As a result of increasing world crude oil and fertilizer prices, input costs will increase. The increase input costs will reduce the use of inputs and paddy yields. On the other hand, if there is excess input usage, energy efficiency will also be reduced.

The aims of the study were to survey input energy in rice production under two sowing techniques and different seed rate, to investigate the energy consumption and to make an economic analysis of rice in Manipur.

\section{Materials and Methods}

The experiment was consists of two sowing techniques (Broadcasting and Line sowing) with five seed rate $\left(80 \mathrm{~kg} \mathrm{ha}^{-1}, 90 \mathrm{~kg} \mathrm{ha}^{-1}, 100\right.$ $\mathrm{kg} \mathrm{ha}{ }^{-1}, 110 \mathrm{~kg} \mathrm{ha}^{-1}$ and $120 \mathrm{~kg} \mathrm{ha}^{-1}$ ) and replicated thrice in factorial randomised block design. The recommended dose of $\mathrm{N}: \mathrm{P}: \mathrm{K}$ was 60:40:30 kg ha ${ }^{-1}$. The fertilizers were used in the form of urea, single super phosphate and muriate of potash. Full dose of phosphorous and potash along with half dose of urea were applied uniformly as a basal to all the plots three days before sowing. The remaining half dose of nitrogen was applied in two equal splits at active tillering stage (25 DAS) and panicle initiation stages (65 DAS). The experiment was carried out under rainfed condition.

Energy equivalent inputs shown in Table 1 are used to calculate energy inputs and energy 
outputs. Energy indices were calculated using the following relationships (Sartori et al., 2005).

Energy efficiency $=[$ Output energy $(\mathrm{MJ} / \mathrm{ha})] /$ Input energy (MJ/ha)

Energy productivity $=[$ Grain yield $(\mathrm{kg} / \mathrm{ha})] /$ Input energy (MJ/ha)

Energy Intensity = [Input energy $(\mathrm{MJ} / \mathrm{ha})] /$ Grain yield (kg/ha)

Net energy gain $=[$ Output energy $(\mathrm{MJ} / \mathrm{ha})]-$ Input energy (MJ/ha)

Each agricultural input was divided into as direct and indirect energy source. Direct energy sources were labour energy, tractor and/or other implement/machinery used for the particular operation and electric/diesel motor to run water pump, while indirect energy sources included seed of high yielding varieties, fertilizers and chemicals used in the production process; energy sources were classified into renewable and non-renewable. Renewable energy included human, labour, manure and seed, while non-renewable sources included diesel, electricity, chemicals, fertilizers, machinery.

\section{Results and Discussion}

\section{Total energy inputs}

The highest total energy input was observed from $\mathrm{S}_{1} \mathrm{R}_{5}(17790 \mathrm{MJ} / \mathrm{ha})$ and $\mathrm{S}_{2} \mathrm{R}_{5}$ (17786 $\mathrm{MJ} / \mathrm{ha}$ ) whereas the lowest total energy input (17135 MJ/ha) and (17139 MJ/ha) recorded from $S_{1} R_{1}$ and $S_{2} R_{1}$ respectively. The highest in total energy input was due to higher seed rate thereby needs more human labour for harvesting and threshing. Among the energy inputs maximum consumption was contributed by chemical energy followed by mechanical energy and the lowest with human energy. A similar finding of higher energy input due to use of chemical fertilizer in rice production was also reported by Khan et al., (2009).

\section{Direct and indirect energy}

Table 4 shows the direct and indirect energy consumption for different treatments in rice production system. Among the treatments maximum direct energy $4928 \mathrm{MJ} / \mathrm{ha}$ and 4924 $\mathrm{MJ} /$ ha were consumed in the treatment $\mathrm{S}_{2} \mathrm{R}_{5}$ and $S_{1} R_{5}$ respectively. Higher seed rate require more human labour for cultivation practices resulting to more direct energy. Line sowing required more energy than the broadcasting. Indirect energy consumption was also observed in the same trend. The highest indirect energy consumption (12862 $\mathrm{MJ} / \mathrm{ha}$ ) was observed from $\mathrm{S}_{1} R_{5}$ and $\mathrm{S}_{2} R_{5}$.

\section{Renewable energy and Non-renewable energy}

Renewable energy system in the rice production was very low and showed that rice production was based on non-renewable resources that these sources cause the environment pollution.

\section{Total energy output}

Highest output energy $217542 \mathrm{MJ} / \mathrm{ha}$ was obtained from $S_{2} R_{3}$ followed by $S_{2} R_{4}(211553$ $\mathrm{MJ} / \mathrm{ha}$ ). The lowest output energy (199054 $\mathrm{MJ} / \mathrm{ha}$ ) was observed from $\mathrm{S}_{1} \mathrm{R}_{1}$ that is broadcasting of lower seed rate $80 \mathrm{~kg} / \mathrm{ha}$. This shows that broadcasting with lower seed rate produced less yield due to less plant population per unit area. On the other hand this observation could also be argued by the statement that overusing of inputs caused increment in consumed energy and lower yield of rice. Similar finding was also reported by Alipour et al., (2012). Higher output energy can be obtained when $110 \mathrm{~kg}$ 
seed/ha was sown in line because of more grain yield per unit area.

\section{Energy indices}

\section{Energy efficiency}

Figure 1 shows the energy efficiency of different sowing technique with different seed rate. According to rice, energy output and energy expenditure, the highest energy efficiency of rice production was observed from $S_{2} R_{3}$ followed by $S_{2} R_{2}$. This shows a better use of input energy in line sowing with seed rate of $100 \mathrm{~kg} / \mathrm{ha}$ and $90 \mathrm{~kg} / \mathrm{ha}$. The lowest energy efficiency observed in $S_{1} R_{5}$ could be as a result of inefficient use of some energy inputs due to inefficient irrigation system. This finding are in contrast with Alipour et al., (2012) that rice energy ratio in Guilan province of Iran was 2.19 lower than 6.7 rice energy ratio index estimated in Australia by Khan et al., (2010).

\section{Energy productivity}

Energy productivity is the yield of marketable product, that is, rice grain per unit of energy consumed. The higher the value $(>1)$, the more energy efficient is the production system. The highest energy productivity of grain (0.35) was obtained from $S_{2} R_{3}$ and the lowest (0.29) from $S_{1} R_{5}$. The lowest energy productivity may be due to use of higher seed rate i.e. $120 \mathrm{~kg} / \mathrm{ha}$.

Table.1 Energy equivalents for different inputs and outputs in rice

\begin{tabular}{|c|c|c|c|c|}
\hline \multicolumn{2}{|c|}{ Items } & Unit & $\begin{array}{c}\text { Energy equivalent } \\
\text { (MJ/unit) }\end{array}$ & Reference \\
\hline & \multicolumn{4}{|l|}{ Input } \\
\hline \multirow[t]{2}{*}{1.} & Fuel & & & \\
\hline & Diesel & $\mathrm{L}$ & 56.31 & Cherati et al., 2011 \\
\hline 2. & Human labour & $\mathrm{hr}$ & 2.31 & Yaldiz et al., 1993 \\
\hline \multirow[t]{4}{*}{3.} & \multicolumn{4}{|l|}{ Fertilizer } \\
\hline & Nitrogen & $\mathrm{kg}$ & 60.6 & Esengun et al., 2007 \\
\hline & Phosphate $\left(\mathrm{P}_{2} \mathrm{O}_{5}\right)$ & $\mathrm{kg}$ & 11.93 & Esengun et al., 2007 \\
\hline & Potassium $\left(\mathrm{K}_{2} \mathrm{O}\right)$ & $\mathrm{kg}$ & 6.7 & Esengun et al., 2007 \\
\hline \multirow[t]{4}{*}{4.} & \multicolumn{4}{|l|}{ Pesticides } \\
\hline & Insecticide & $\mathrm{kg}$ & 101.2 & Yaldiz et al., 1993 \\
\hline & Herbicide & $\mathrm{kg}$ & 238 & Pathak and binning, 1985 \\
\hline & Fungicide & $\mathrm{kg}$ & 216 & Pathak and binning, 1985 \\
\hline \multirow[t]{4}{*}{5.} & Seed & $\mathrm{kg}$ & 17 & Singh and Mital, 1992 \\
\hline & Output & & & \\
\hline & Paddy & $\mathrm{kg}$ & 14.7 & Moradi and Azarpour, 2011 \\
\hline & Straw & $\mathrm{kg}$ & 12.5 & Moradi and Azarpour, 2011 \\
\hline
\end{tabular}


Table.2 Energy inputs used in rice production system under different sowing technique and seed rate

\begin{tabular}{|c|c|c|c|c|c|}
\hline Treatment & $\begin{array}{c}\text { Mechanical } \\
\text { energy } \\
\text { (MJ/ha) }\end{array}$ & $\begin{array}{c}\text { Chemical } \\
\text { energy } \\
\text { (MJ/ha) }\end{array}$ & $\begin{array}{c}\text { Biological } \\
\text { energy } \\
\text { (MJ/ha) }\end{array}$ & $\begin{array}{c}\text { Human } \\
\text { energy } \\
\text { (MJ/ha) }\end{array}$ & $\begin{array}{c}\text { Total energy } \\
\text { inputs } \\
\text { (MJ/ha) }\end{array}$ \\
\hline $\mathbf{S}_{1} \mathbf{R}_{1}$ & 4730 & 11002 & 1240 & 162.68 & 17135 \\
\hline $\mathbf{S}_{1} \mathbf{R}_{2}$ & 4730 & 11002 & 1395 & 170.52 & 17298 \\
\hline $\mathbf{S}_{1} \mathbf{R}_{3}$ & 4730 & 11002 & 1550 & 178.36 & 17461 \\
\hline $\mathbf{S}_{1} \mathbf{R}_{\mathbf{4}}$ & 4730 & 11002 & 1705 & 186.20 & 17624 \\
\hline $\mathbf{S}_{1} \mathbf{R}_{5}$ & 4730 & 11002 & 1860 & 194.04 & 17786 \\
\hline $\mathbf{S}_{2} \mathbf{R}_{1}$ & 4730 & 11002 & 1240 & 166.60 & 17139 \\
\hline $\mathbf{S}_{2} \mathbf{R}_{2}$ & 4730 & 11002 & 1395 & 174.44 & 17302 \\
\hline $\mathbf{S}_{2} \mathbf{R}_{3}$ & 4730 & 11002 & 1550 & 182.28 & 17465 \\
\hline $\mathbf{S}_{2} \mathbf{R}_{4}$ & 4730 & 11002 & 1705 & 190.12 & 17628 \\
\hline $\mathbf{S}_{\mathbf{2}} \mathbf{R}_{\mathbf{5}}$ & 4730 & 11002 & 1860 & 197.96 & 17790 \\
\hline \multicolumn{6}{|c|}{$\begin{array}{l}S_{1}-\text { Broadcasting; } S_{2}-\text { Line sowing; } R_{1}-80 \mathrm{~kg} \mathrm{ha}^{-1}, R_{2}-90 \mathrm{~kg} \mathrm{ha}^{-1}, R_{3}-100 \mathrm{~kg} \mathrm{ha}^{-1}, R_{4}-110 \mathrm{~kg} \mathrm{ha}^{-1} \text { and } \\
R_{5}-120 \mathrm{~kg} \mathrm{ha}^{-1}\end{array}$} \\
\hline
\end{tabular}

Table.3 Different energy requirement for different treatment

\begin{tabular}{|c|c|c|c|c|}
\hline Treatment & $\begin{array}{l}\text { Direct energy } \\
\text { (MJ/ha) }\end{array}$ & $\begin{array}{c}\text { Indirect energy } \\
(\mathrm{MJ} / \mathrm{ha})\end{array}$ & $\begin{array}{c}\text { Renewable } \\
\text { energy (MJ/ha) }\end{array}$ & $\begin{array}{l}\text { Non-renewable } \\
\text { energy (MJ/ha) }\end{array}$ \\
\hline $\mathbf{S}_{1} \mathbf{R}_{1}$ & 4893 & 12242 & 1403 & 15732 \\
\hline $\mathbf{S}_{1} \mathbf{R}_{2}$ & 4901 & 12397 & 1566 & 15732 \\
\hline $\mathbf{S}_{\mathbf{1}} \mathbf{R}_{\mathbf{3}}$ & 4908 & 12552 & 1728 & 15732 \\
\hline $\mathbf{S}_{1} \mathbf{R}_{4}$ & 4916 & 12707 & 1891 & 15732 \\
\hline $\mathbf{S}_{1} \mathbf{R}_{5}$ & 4924 & 12862 & 2054 & 15732 \\
\hline $\mathbf{S}_{2} \mathbf{R}_{1}$ & 4897 & 12242 & 1407 & 15732 \\
\hline $\mathbf{S}_{2} \mathbf{R}_{2}$ & 4904 & 12397 & 1569 & 15732 \\
\hline $\mathbf{S}_{\mathbf{2}} \mathbf{R}_{\mathbf{3}}$ & 4912 & 12552 & 1732 & 15732 \\
\hline $\mathbf{S}_{2} \mathbf{R}_{4}$ & 4920 & 12707 & 1895 & 15732 \\
\hline $\mathbf{S}_{\mathbf{2}} \mathbf{R}_{\mathbf{5}}$ & 4928 & 12862 & 2058 & 15732 \\
\hline \multicolumn{5}{|c|}{$\begin{array}{l}S_{1}-\text { Broadcasting; } S_{2}-\text { Line sowing; } R_{1}-80 \mathrm{~kg} \mathrm{ha}^{-1}, \mathbf{R}_{2}-90 \mathrm{~kg} \mathrm{ha}^{-1}, \mathbf{R}_{3}-100 \mathrm{~kg} \mathrm{ha}^{-1}, \mathbf{R}_{4}-110 \mathrm{~kg} \mathrm{ha}^{-1} \text { and } \\
\mathbf{R}_{5}-120 \mathrm{~kg} \mathrm{ha}^{-1}\end{array}$} \\
\hline
\end{tabular}


Table.4 Energy output obtained in rice production system under different sowing technique and seed rate

\begin{tabular}{|c|c|c|c|}
\hline Treatment & $\begin{array}{c}\text { Grain yield } \\
\left.\text { (kg ha }^{-1}\right)\end{array}$ & $\begin{array}{l}\text { By-product } \\
\left(\mathrm{kg} \mathrm{ha}^{-1}\right)\end{array}$ & $\begin{array}{c}\text { Total energy output } \\
\left(\mathrm{MJ} \mathrm{ha}^{-1}\right)\end{array}$ \\
\hline $\mathbf{S}_{1} \mathbf{R}_{1}$ & 5208 & 9466 & 199054 \\
\hline $\mathbf{S}_{1} \mathbf{R}_{2}$ & 5639 & 9597 & 207361 \\
\hline $\mathbf{S}_{\mathbf{1}} \mathbf{R}_{\mathbf{3}}$ & 5706 & 9733 & 210108 \\
\hline $\mathbf{S}_{1} \mathbf{R}_{4}$ & 5436 & 9633 & 204677 \\
\hline $\mathbf{S}_{1} \mathbf{R}_{5}$ & 5164 & 9667 & 200874 \\
\hline $\mathbf{S}_{2} \mathbf{R}_{1}$ & 5578 & 9633 & 206870 \\
\hline $\mathbf{S}_{2} \mathbf{R}_{2}$ & 5706 & 9700 & 209695 \\
\hline $\mathbf{S}_{\mathbf{2}} \mathbf{R}_{\mathbf{3}}$ & 6030 & 9926 & 217542 \\
\hline $\mathbf{S}_{2} \mathbf{R}_{\mathbf{4}}$ & 5695 & 9863 & 211553 \\
\hline $\mathbf{S}_{2} \mathbf{R}_{5}$ & 5406 & 9889 & 207403 \\
\hline \multicolumn{4}{|c|}{$\begin{array}{l}S_{1}-\text { Broadcasting; } S_{2}-\text { Line sowing; } R_{1}-80 \mathrm{~kg} \mathrm{ha}^{-1}, R_{2}-90 \mathrm{~kg} \mathrm{ha}^{-1}, R_{3}-100 \mathrm{~kg} \mathrm{ha}^{-1}, R_{4} \\
-110 \mathrm{~kg} \mathrm{ha}^{-1} \text { and } R_{5}-120 \mathrm{~kg} \mathrm{ha}^{-1}\end{array}$} \\
\hline
\end{tabular}

Fig 1 (a) Energy Efficiency

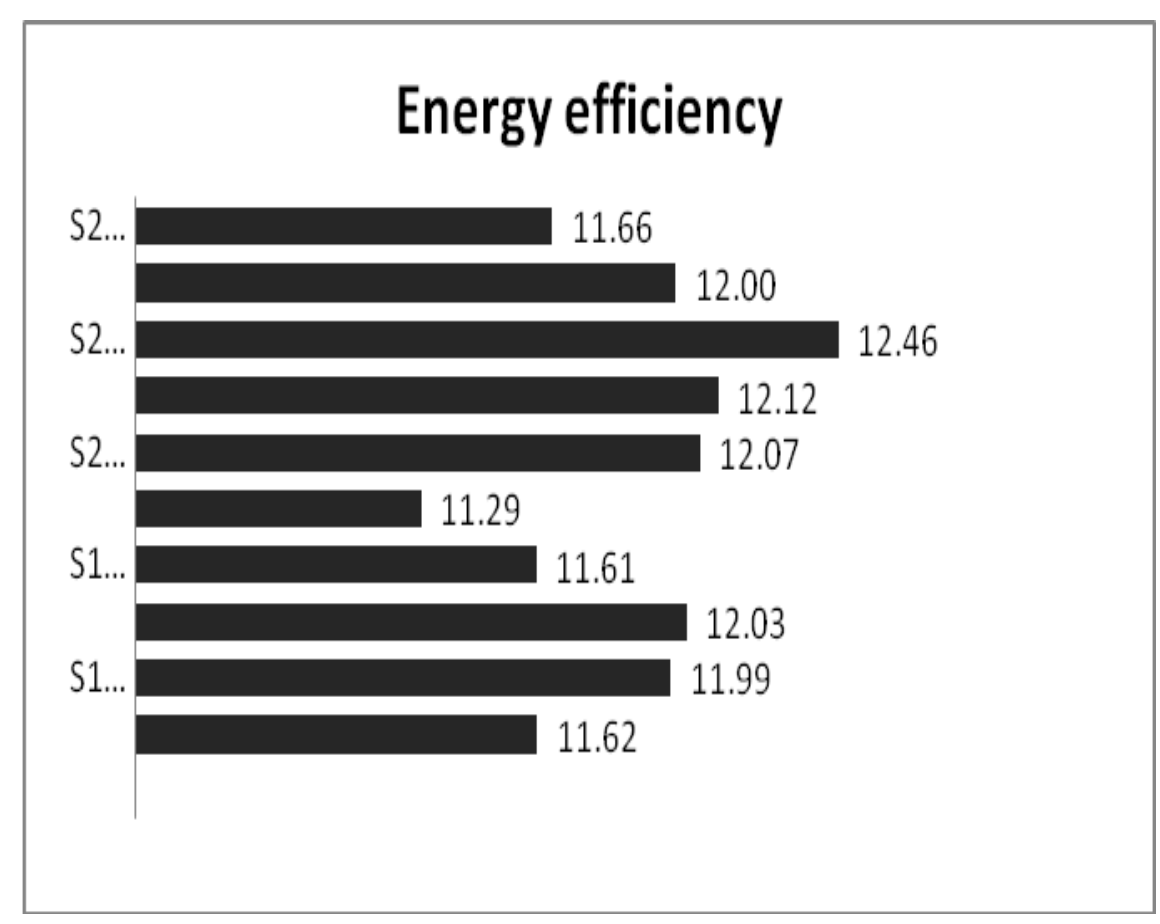


(b) Energy productivity

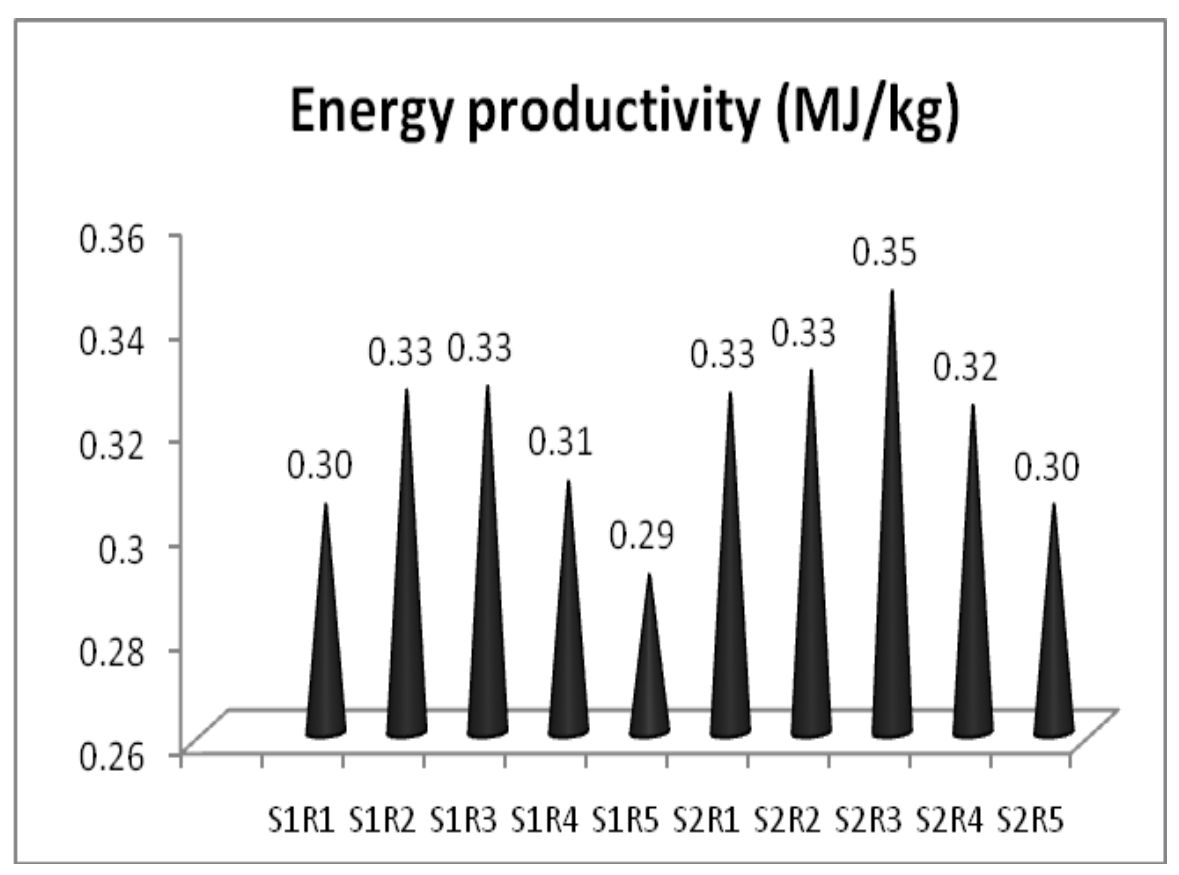

(c) Energy Intensity

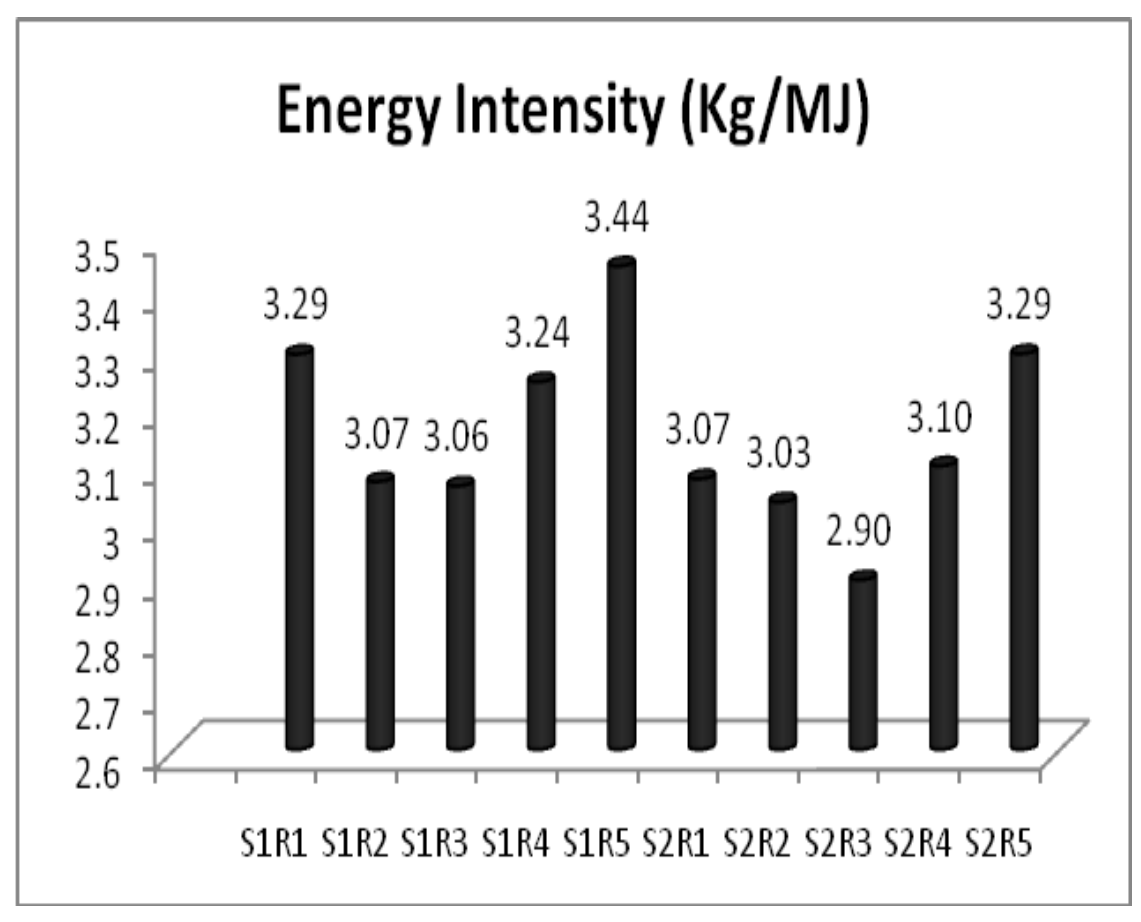


(d) Net energy gain

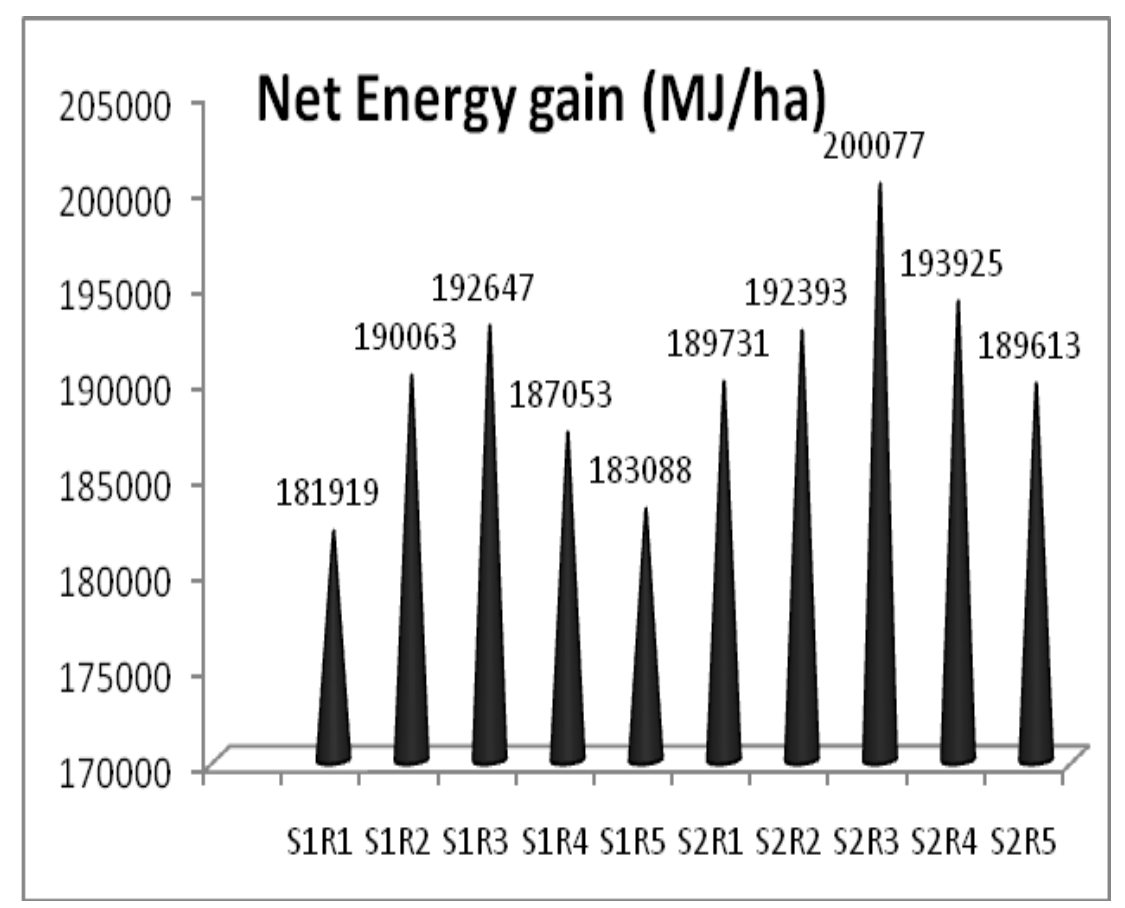

\section{Energy intensity}

Energy intensity is an index which shows how much energy was used to produce one unit of disposable/ marketable yield (rice grain). The lower the index the more efficient is the use of energy in the production system. Energy intensity shows that the highest energy consumption was for $\mathrm{S}_{1} \mathrm{R}_{5}(3.44 \mathrm{MJ} / \mathrm{ha})$ and the lowest for $\mathrm{S}_{2} \mathrm{R}_{3}(2.90 \mathrm{MJ} / \mathrm{ha})$. Figure 1 (c) shows that about $3.44 \mathrm{MJ} / \mathrm{ha}$ of energy is required to produce only a kilogram of paddy in the treatment $S_{1} R_{5}$. This implies that there was low grain output in respect to energy inputs used in the production process due to inefficient energy inputs used. The highest net energy gain $(200.08 \mathrm{GJ} / \mathrm{ha})$ was from $\mathrm{S}_{2} \mathrm{R}_{3}$ and the lowest (181.92 GJ/ha) from $S_{1} R_{1}$.

In conclusion, a quantitative energy inputoutput analysis of rice production was studied based on the level of energy consumption, forms of energy and some energy indices such as energy ratio, specific energy, energy productivity and net energy. From the above investigation it can be concluded that highest energy output, energy efficiency and highest energy productivity of grain were obtained from line sowing with seed rate $100 \mathrm{~kg} / \mathrm{ha}$.

\section{Acknowledgement}

Authors are thankful to the Dean, College of Agriculture, Central Agricultural University, Imphal for all the financial and technical support to carry out this research.

\section{References}

Adem Hatirli, S., Ozkan, B. and Fert, C. (2006). Energy inputs and crop yield relationship in greenhouse tomato production. Renewable Energy 31: 427438.

Alipour, A., Veisi, H., Darijani, F., Mirbagherim B, and Behbahani, A.G. (2012). Study and determination of energy consumption to produce conventional rice of the Guilan province. Res. Agr. Eng. 58(3):99-106. 
Cherati, F.E., Bahrami, H. and Asakereh, A. (2011). Energy survey of mechanized and traditional rice production system in Mazandaran Province of Iran. Afr. J. Agric. Res. 6(11): 2565-2570.

Esengun, K., Gunduz, O. and Erdal, G. (2007). Input-output energy analysis in dry apricot production of Turkey. Energy. Conver. Manage. 48: 592-598.

Farshad, A., Zinck, J.A. (2001). Assessing Agricultural Sustainability Using the Six-Pillar Model: Iran as a Case Study. In: Gliessman S.R., Agroecosystem Sustainability: Developing Practical Strategies. Boca Raton, CRC Press: 137-152.

Khan, M.A., Awan, I.U. and Zafar, J. (2009). Energy requirement and economic analysis of rice production in western part of Pakistan. Soil and Environment 28(1), 60-67.

Khan, S., Khan, M.A., Latif, N. (2010). Energy Requirements and Economic Analysis of Wheat, Rice and Barley Production in Australia. J. Soil Environ. 29(1): 61-68.

Moradi, M. and Azarpour, E. (2011). Study of energy indices for native and breed rice varieties production in Iran. World Appl. Sci. J., 13(1): 137-141.0.

Ozkan, B., Akcaoz, H. and Karadeniz, F. (2004). Energy requirement and economic analysis of citrus production in Turkey. Energy Conver. Manage. 45: 1821-1830.

Pathak, B. and Binning, A. (1985). Energy use pattern and potential for energy saving in rice-wheat cultivation. Agric. Energy, 4: 271-280.

Pervanchon, F., Bockstaller, C. and Girardinc, P. (2002). Assessment of energy use in arable farming systems by means of an agro-ecological indicator: the energy indicator. Agricultural Systems, 72: 149-172.

Sartori, L., Basso, B., Bertocco, M. and Oliviero, G. (2005). Energy use and economic evaluation of a three year crop rotation for conservation and organic farming in NE Italy. Biosyst. Eng., 9(2): 245-250.

Singh, S. and Mital, J.P. (1992). Energy in Production Agriculture. Mittal Pub, New Delhi.

Sinha, S.K. and Talati, J. (2007). Productivity impacts of the system of rice intensification (SRI): A case study in West Bengal, India. Agr. Water Manag. 87: $55-60$.

Yaldiz, O., Ozturk, H.H., Zeren, Y. and Bascetincelik, A. (1993). Energy Usage in Production of Field Crops in Turkey. In: Vth International Congress on Mechanization and Energy in Agriculture. Izmir- Turkey 527-536 pp

\section{How to cite this article:}

Nandini Dev, K., Herojit Singh Athokpam, K. Khamba Singh, M. Anandi Devi and Gojendro Singh, O. 2020. Comparison of Energy Consumption for Different Sowing Techniques and Seed Rate of Direct Seeded Rice (Oryza sativa L.) under Medium Land Situation of Manipur. Int.J.Curr.Microbiol.App.Sci. 9(03): 328-336. doi: https://doi.org/10.20546/ijcmas.2020.903.039 